\title{
A Study Of Factors Affecting University Professors' Research Output: Perspectives Of Taiwanese Professors
}

\author{
Jason Cheng-Cheng Yang, National Chiayi University, Taiwan
}

\begin{abstract}
Higher education in Taiwan is facing competition and challenges from the macro environment of globalization. Taiwan's key policy direction is enhancing university quality in order to respond to these future trends. Universities' international competitiveness relies on not only faculty members' teaching quality, but also their research performance. Faculty members' research performance strongly affects a university's reputation, funding generation, and attraction of international and local students. Reviewing the higher education development in Taiwan, although policymakers have continued to promote the benefits of differentiating universities, few studies care how environmental factors of different types of universities affect faculty members' research performance. Currently, fewer studies focus on the influence of environmental factors on professors' research performance. In addition, few studies have explored the structural inequalities between universities. This research contains two sequential research methods-namely, analytic hierarchy process and questionnaire survey-to accomplish the following purposes: exploring related literature; determining key indicators of environmental factors; comparing the relative weights of key indicators in Taiwan; comparing the cognitive evaluation of environmental factors perceived by university professors at four different types of universities in Taiwan; and comparing the cognitive evaluation of environmental factors perceived by university professors in Taiwan.
\end{abstract}

Keywords: Higher Education; Professor; Research Production; Taiwan

\section{INTRODUCTION}

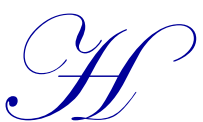

igher education system of Taiwan has faced structural transformation in the last twenty years; the most significant change has been in the total number of universities. By 2000, the total number of higher education institutions had risen to 150. The different types of universities had also changed, resulting in 67 general comprehensive universities, 59 technological universities, and 13 junior colleges in the year of 2016 (Ministry of Education in Taiwan, 2017). The structural transformation of higher education showed that the entire higher education system in Taiwan is a two pathway system, with one focusing on comprehensive general universities and the other technological universities (Lin \& Chan, 2004).

Despite the transformation of higher education, globalization and the international mobility of students also fostered national governments in Asia to emphasize the quality of higher education (Hou, 2012). In more recent years, the main focus of the Taiwanese government's higher education policy has been on fostering world class universities (Chen \& Lo, 2013). Taiwan's government implemented its Building World Class University Policy as well as its Promoting Teaching Excellence of Universities started from the year of 2005 to enhance research and teaching quality and internationalization (Lo, 2009). Quality assurance of higher education — whether based on international evaluation, national evaluation, or international higher education rankings-has defined university professors' research performance as a key indicator because their research and publications relate to their teaching contents as well as to university reputation, funding, and industry linkage.

In Asia, countries such as Taiwan, Japan, and South Korea, the social form is closer to collectivism. In such societies, people are expected to have high moral standards, especially in the field of education (Zhang, Lin, Nonaka, \& Beom, 2005). Thus, although some studies have examined factors of university professors' research 
performance, the impact factors and their relative importance might be different in Asian and Western societies. In recent years, the most significant trend of educational change has been marketization, including industrial management in school administration to enhance school effectiveness. This trend is even more significant in higher education. Governments throughout the world have been influenced by neo-liberalism to promote the corporatization of public universities, enhance university autonomy, and strengthen the competition mechanism in higher education (Giroux, 2002; Olssen \& Peters, 2005). Therefore, universities in the world have become devoted to promoting professors' research performance, which influences universities' ranking and student recruitment. Thus far, few studies have examined influential factors of professors' research outcomes in Asia. Comparing the differences of influential factors of research production in Asian and Western countries that have academic contribution can also help construct a research-friendly environment inside universities. Second, regardless of whether in national, domestic, or international research contexts, more and more inequality issues are emerging within universities due to the impact of globalization. Thus, it is important to study how and the extent to which university professors' challenges of doing research inside different universities can help uncover structural inequalities of higher education throughout the world.

This research first conducted a literature review to identify important factors influencing university professors' research performance; second, it designed a questionnaire based on the literature review, called the Questionnaire of Weights of Influential Factors of University Professors' Research Performance, and administered this questionnaire to university professors at different universities in Taiwan. Thus, this research can help define environmental factors helping professors conduct research at different types of academic institutions in Taiwan. Ultimately, the research purposes are:

1. To analyze related literature about studying university professors' research performance;

2. To identify significant factors that influence university professors' research performance;

3. To calculate weights of influential factors of university professors' research performance;

4. To compare current conditions of environmental factors at different types of universities perceived by university professors in Taiwan; and

5. To provide implications for practical higher education administration and future academic research.

\section{LITERATURE REVIEW}

\subsection{What is University Professors' Research Performance?}

This section first defines the concept of university professors' research performance based on the relevant literature. Chang and Chiu (2008) divides university professors' research performance into several indexes: research project, journal article publication, book and book chapter publication, conference paper, patent acquired via research results, and academic award. In terms of how to measure university professors' research performance, Creswell (1985) reviewed literature from the 1960s to the 1980s and found that the main indexes for measuring university professors' research performance include the number of research articles and number of citations of research articles. However, these indexes cannot represent the real quality of research articles and may cause problems in overemphasizing quantity versus quality; thus, some scholars thought peer ratings or peer reviews could be a better way to evaluate university professors' research performance (Campbell, 2002).

\subsection{Factors that Influence University Professors' Research Performance}

In terms of factors of influencing university professors' research performance, Creswell (1985) reviewed research articles published in the 1960s, 1970s, and 1980s in the United States about the exploration of factors influencing university professors' research publication and determined that factors can be divided into individual factors and environmental factors. Individual factors include IQ, motivation, perception of stress, age, and gender. Environmental factors include university reputation, resource allocation, academic colleagues, and research field. Creswell (1985) suggested that future studies apply diversified and interdisciplinary methods to explore the effect of institutional and research field differences on university professors' research performance. 
Creswell's (1985) research lacked a discussion about the impact of organizational climate on university professors' research performance. University reputation represents the whole university's atmosphere. However, professors' perceptions of climate effects on individuals inside the campus should not be neglected. The relevant literature found that organizational climate significantly influences internal individuals' behavior and performances inside universities (Moran \& Volkwein, 1988). Kotrlik, Bartlett, Higgins, and Williams (2001) found that graduate students' ability and confidence in conducting research as well as research assistants' ability significantly influence university professors' research article production. Blackburn and Bentley (1993) argued that, although university professors' psychological perception and background variables, such as stress, motivation, gender, and age, influence their research production, environmental factors, such as research support culture, good research space and facilities, and good colleague interaction, are also important variables for predicting university professors' research production.

Chen, Gupta, and Hoshower (2006) studied 320 university professors who taught in business school to explore their perceptions about important factors of research article production. The research findings revealed that assistant professors tend to be influenced by external rewards, such as promotion and money, but associate professors tend to be influenced by their internal psychological feelings. Their research also demonstrated that research article production has a negative relationship with years of employment at universities. No significant difference emerged between research field and gender. Kyvik and Smeby (1994) found a relationship between graduate student behavior and professors' research performance. For professors who worked in the fields of natural sciences, medicine, and engineering, when their graduate students' theses related to their research field, their research production significantly increased.

\section{RESEARCH METHOD}

The research purposes of this study were to construct influential factors of research performance perceived by university professors in Taiwan, calculate the relative weight of each influential factor, and compare the importance given to these influential factors perceived by university professors. This research used the analytic hierarchy process (AHP) as the main statistical method to measure the relative importance of the influential factors, and the statistical methods of ANOVA and $t$-test were used to determine if significant differences existed among the perceptions of university professors in Taiwan.

\subsection{Research Aim and Research Questions}

Conducting research is an important goal of faculty around the world; it is also a significant aim of the Taiwanese government. Scientific research publications also stimulate social development and technology innovation as well as human wellness. Thus, determining how to stimulate university faculty members' research production is the key research question for this study. The research sub-questions include the following four questions:

3.3.1 What are the importance weights that university professors in Taiwan rate for influential factors on research production?

\subsubsection{Do the weight differences significantly exist amongst university professors from different backgrounds?}

3.1.3 What are university professors' perspectives on their working universities' current conditions of these influential factors?

3.1.4 Do significant differences in the current conditions of these influential factors exist amongst professors from different backgrounds?

\subsection{The Analytic Hierarchy Process}

The analytic hierarchy process (AHP) is a research method that can help analyze best decisions based on structured techniques (Ho, 2013). AHP can help find out the best solution when leaders are considering making a decision. In policy and administration studies, it also used to define the relative weights of constructions of best policy or practice (Saaty, 1990). AHP was used as the main research method of in the current research because it is often 
viewed as the best method in determining the relative importance of various factors (Saaty, 1990). In this research, AHP is used to help identify the relative importance of influential factors that Taiwanese professors think which factor will possess higher influence on their research performance.

This research constructed a questionnaire concept structure of influential factors of university faculty research production based on the AHP structure in Figure 1. The primary goal, located at the highest level, is identifying the influential factors of university faculty research production. On the second level are the five indicators of influential factors: research funding, organizational climate, hardware and facilities, human resources, and library and journal resources. The third level includes the 15 sub-indicators: governmental research funding, private sector research funding, institutional research funding, departmental research atmosphere, colleagues' research collaboration relationship, leaders' support on academic research, information technology on campus, research discussion spaces on campus, research or experiment facilities on campus, students' academic achievement, research assistants' ability, colleagues' academic capacity, paper book and journal resources on campus, digital book and journal resources on campus, and research software and coding resources on campus.

Figure 1. Concept Structure of Influential Factors of University Faculty Research Production

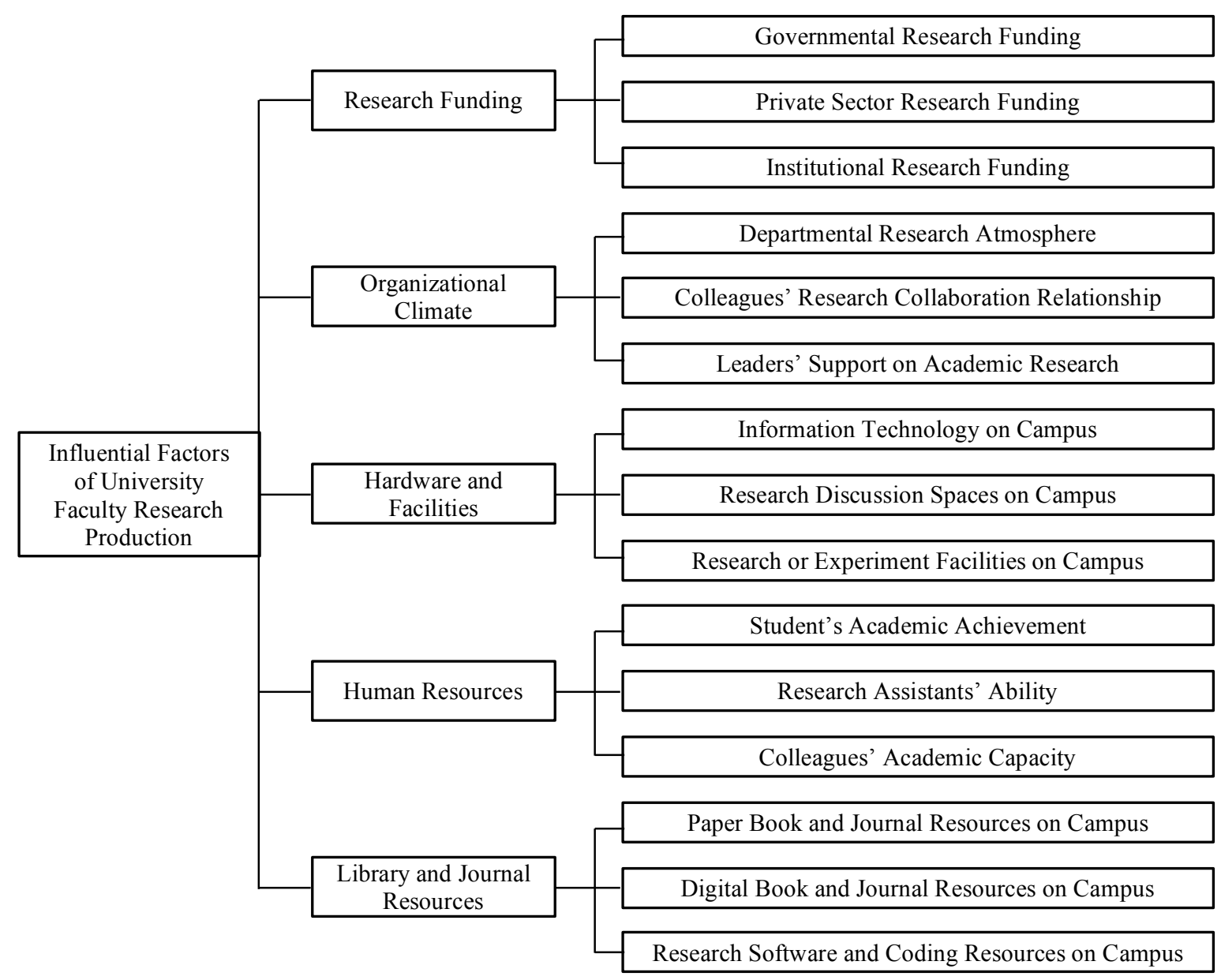

\subsection{Research Questionnaire Structure}

A self-developed AHP questionnaire based on the literature review is constructed. The Chinese written questionnaire was used to survey Taiwanese professors who worked at different academic institutions in Taiwan. The questionnaire can be divided into three parts. The first part collected background information, the second part 
consisted of 15 pairwise questions about the relative importance of influential factors of research production, and the third part included 15 questions on the influential factors used and the effectiveness of these factors in Taiwan.

The questionnaires were sent to 500 professors from 15 comprehensive universities located in the northern, central, southern, and eastern regions of Taiwan. Ultimately, 120 questionnaires were returned, resulting in a $24 \%$ retrieval rate. In these 120 questionnaires, 66 were male, and 54 were female; 48 were associate professors or above while 72 were assistant professors. In addition, 90 participants worked at universities in six urban cities of Taiwan whereas the others taught at universities in other cities. Table 1 summarizes the number and percentage of returned questionnaires as well as participants' background information. The distributions are balanced in terms of university location, research field, gender, academic rank, and type of university.

Table 1. Number and Percentage of Returned Questionnaires and Background Variable Information

\begin{tabular}{|c|c|c|c|}
\hline \multicolumn{2}{|l|}{ 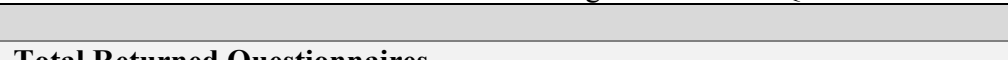 } & $\mathbf{N}$ & Percentage \\
\hline \multicolumn{2}{|l|}{ Total Returned Questionnaires } & 120 & $100 \%$ \\
\hline \multirow{2}{*}{ Gender } & Male & 66 & $55 \%$ \\
\hline & Female & 54 & $45 \%$ \\
\hline \multirow{2}{*}{ Position Rank } & Associate Professor and Above & 48 & $40 \%$ \\
\hline & Assistant Professor & 72 & $60 \%$ \\
\hline \multirow{4}{*}{ Type of University } & National University & 30 & $25 \%$ \\
\hline & Private University & 48 & $40 \%$ \\
\hline & National Technology University & 12 & $10 \%$ \\
\hline & Private Technology University & 30 & $25 \%$ \\
\hline \multirow{2}{*}{$\begin{array}{l}\text { University with World Class University } \\
\text { Fund? }\end{array}$} & Yes & 36 & $30 \%$ \\
\hline & No & 84 & $70 \%$ \\
\hline \multirow{2}{*}{ Location } & Six Urban Cities & 90 & $75 \%$ \\
\hline & Other Cities & 30 & $25 \%$ \\
\hline \multirow{6}{*}{ Research Field } & Life Sciences & 18 & $15 \%$ \\
\hline & Natural Sciences & 18 & $15 \%$ \\
\hline & Engineering & 48 & $40 \%$ \\
\hline & Social Sciences & 12 & $10 \%$ \\
\hline & Education & 6 & $5 \%$ \\
\hline & Management & 18 & $15 \%$ \\
\hline \multirow{5}{*}{$\begin{array}{l}\text { Total Number of Journal Articles } \\
\text { Published in the Last Five Years }\end{array}$} & None & 12 & $10 \%$ \\
\hline & $1-3$ & 24 & $20 \%$ \\
\hline & $4-6$ & 48 & $40 \%$ \\
\hline & $7-9$ & 18 & $15 \%$ \\
\hline & 10 or more & 18 & $15 \%$ \\
\hline
\end{tabular}

\section{FINDINGS}

Figure 2 presents the results of Taiwanese professors' opinions on the importance weights of influential factors of research production. The highest weight goes to research funding factor, followed by human resources, library and journal resources, organizational climate, and hardware and facilities.

Figure 3 depicts the weight scores of sub-indicators of influential factors of research production. Among the 15 subindicators of influential factors of research production, the highest score goes to governmental research funding, followed by students' academic achievement, and digital book and journal resources. The least important factors were discussion spaces on campus, paper book and journal resources, and colleagues' research collaboration relationship. 
Figure 2. Weight scores of first- and second-level influential factors rated by university professors in Taiwan

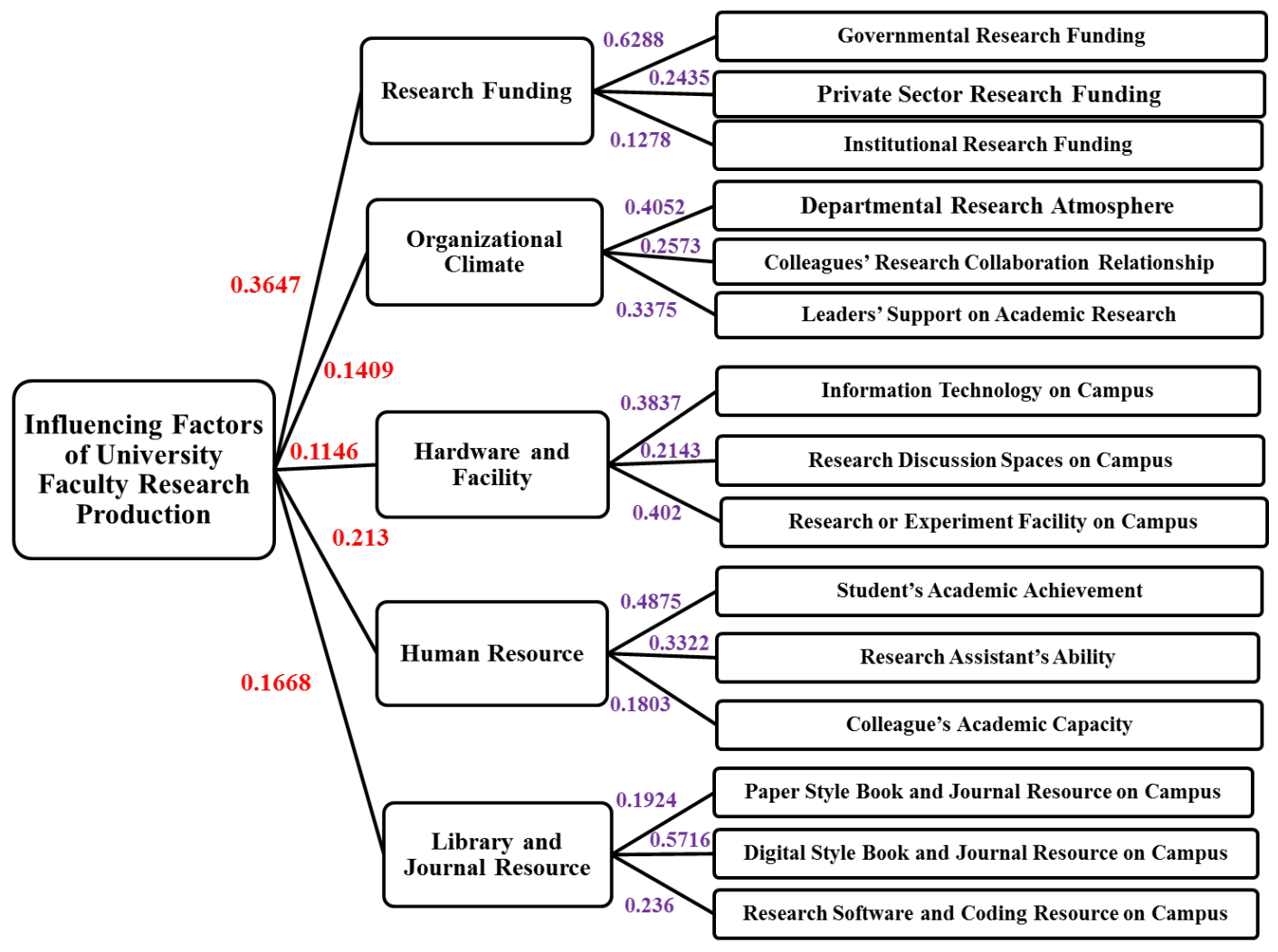

Figure 3. Weight scores of third-level influential factors rated by university professors in Taiwan

Influencing Factors of University Faculty Research Production

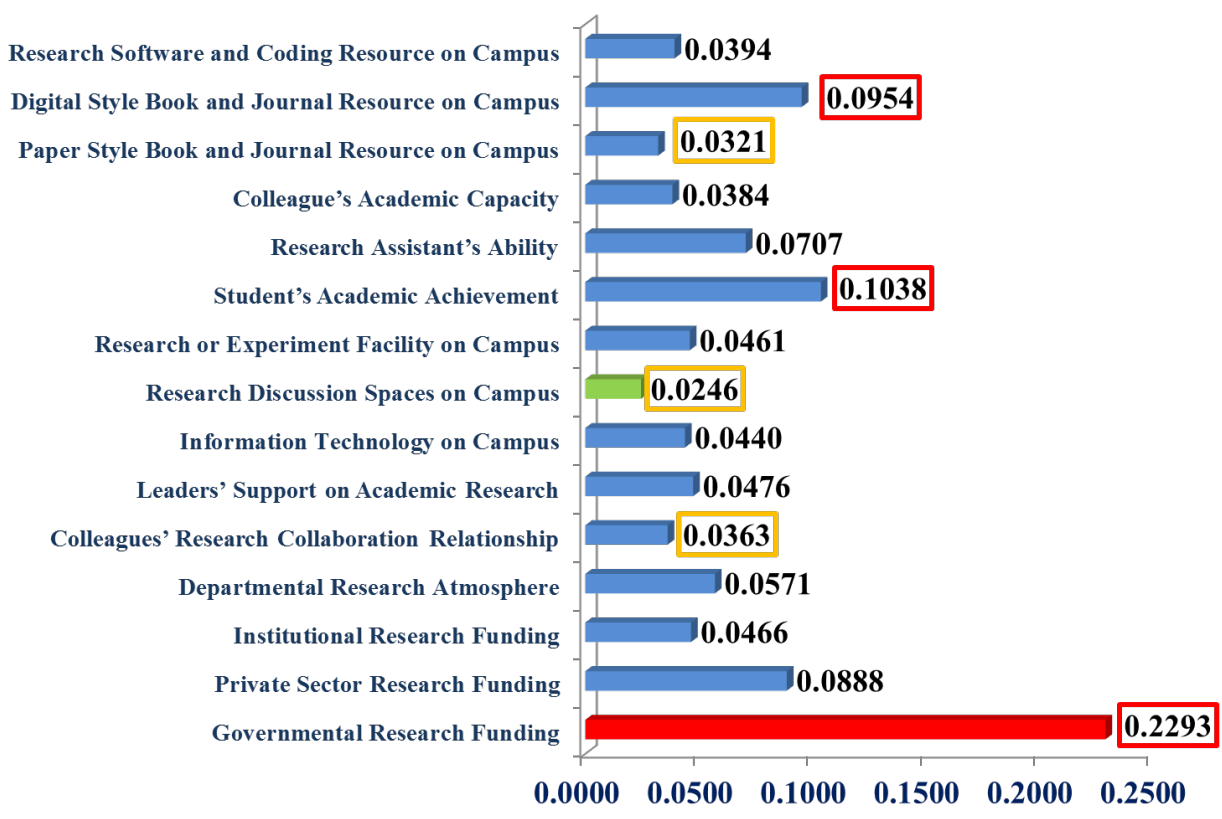


Table 2 summarizes the mean and standard deviations (SD) of Taiwanese professors' opinions on influential factors being used in their universities. Professors rated their satisfaction with the effectiveness of these factors in their universities. Taiwanese professors tended to be more satisfied with organizational climate factors and hardware and facilities. They felt less satisfied with their research funding.

Table 2. Taiwanese Professors' Perceived Satisfaction with Influential Factors at Their Universities

\begin{tabular}{l|c|c|c}
\hline & N & Mean & SD \\
\hline Research Funding & 120 & 2.9167 & .78412 \\
\hline Organizational Climate & 120 & 3.3333 & .94083 \\
\hline Hardware and Facility & 120 & 3.3000 & .97533 \\
\hline Human Resources & 120 & 3.1333 & .68108 \\
\hline Library and Journal Resources & 120 & 3.1833 & .71381 \\
\hline
\end{tabular}

Table 3 summarizes the mean and SD of Taiwanese professors' opinions on sub-indicators of influential factors being used in their universities. Professors rated their satisfaction with the effectiveness of these sub-indicators in their universities. Taiwanese professors tended to be more satisfied with their colleagues' academic capacity, research collaboration, and information technology on campus. They felt less satisfied with their governmental research funding, students' academic achievement, and institutional research funding.

Table 3. Taiwanese Professors' Perceived Satisfaction with Influential Factors at Their Universities: Sub-indicators

\begin{tabular}{|c|c|c|c|}
\hline $\begin{array}{ll}\text { Items } \\
\end{array}$ & $\mathbf{N}$ & Mean & SD \\
\hline 1. Governmental Research Funding & 120 & 2.75 & 1.183 \\
\hline 2. Private Sector Research Funding & 120 & 3.15 & .967 \\
\hline 3. Institutional Research Funding & 120 & 2.85 & 1.113 \\
\hline 4. Departmental Research Atmosphere & 120 & 3.35 & 1.157 \\
\hline 5. Colleagues' Research Collaboration Relationship & 120 & 3.40 & .974 \\
\hline 6. Leaders' Support on Academic Research & 120 & 3.25 & .998 \\
\hline 7. Information Technology on Campus & 120 & 3.40 & .920 \\
\hline 8. Research Discussion Spaces on Campus & 120 & 3.35 & 1.066 \\
\hline 9. Research or Experiment Facilities on Campus & 120 & 3.15 & 1.113 \\
\hline 10. Students' Academic Achievement & 120 & 2.60 & .738 \\
\hline 11. Research Assistants’ Ability & 120 & 3.10 & .999 \\
\hline 12. Colleagues’ Academic Capacity & 120 & 3.70 & .643 \\
\hline 13. Paper Books and Journal Resources on Campus & 120 & 3.15 & .729 \\
\hline 14. Digital Books and Journal Resources on Campus & 120 & 3.20 & .816 \\
\hline 15. Research Software and Coding Resources on Campus & 120 & 3.20 & .875 \\
\hline
\end{tabular}

Table 4 summarizes the $t$-test results according to gender of Taiwanese professors' ratings of their satisfaction with influential factors. Male professors felt significantly higher satisfaction with their research funding than female professors. Female professors were significantly more satisfied with their hardware and facilities than male professors. 
Table 4. Taiwanese Professors' Perceived Satisfaction with Influential Factors: Gender comparison

\begin{tabular}{|c|c|c|c|c|c|c|}
\hline & Gender & $\mathbf{N}$ & Mean & SD & $t$ Value & SIG \\
\hline \multirow{2}{*}{ Research Funding } & Male & 66 & 3.1212 & .78802 & \multirow{2}{*}{$3.287^{* *}$} & \multirow{2}{*}{.001} \\
\hline & Female & 54 & 2.6667 & .70933 & & \\
\hline \multirow{2}{*}{ Organizational Climate } & Male & 66 & 3.2121 & 1.04536 & \multirow{2}{*}{-1.570} & \multirow{2}{*}{.119} \\
\hline & Female & 54 & 3.4815 & .77883 & & \\
\hline \multirow{2}{*}{ Hardware and Facilities } & Male & 66 & 3.1212 & 1.18341 & \multirow{2}{*}{$-2.403^{*}$} & \multirow{2}{*}{.018} \\
\hline & Female & 54 & 3.5185 & .57432 & & \\
\hline \multirow{2}{*}{ Human Resources } & Male & 66 & 3.0909 & .73157 & \multirow{2}{*}{-.753} & \multirow{2}{*}{.453} \\
\hline & Female & 54 & 3.1852 & .61657 & & \\
\hline \multirow{2}{*}{ Library and Journal Resources } & Male & 66 & 3.1515 & .73539 & \multirow{2}{*}{-.538} & \multirow{2}{*}{.591} \\
\hline & Female & 54 & 3.2222 & .69137 & & \\
\hline
\end{tabular}

$* \mathrm{P}<.05 ; * * \mathrm{P}<.01$

Table 5 reports the $t$-test according to rank of Taiwanese professors' ratings of their satisfaction with influential factors. Associate professors and professors felt significantly higher satisfaction with their organizational climate than assistant professors in Taiwan.

Table 5. Taiwanese Professors' Perceived Satisfaction with Influential Factors: Comparison of academic positions

\begin{tabular}{|c|c|c|c|c|c|c|}
\hline & $\begin{array}{l}\text { Position } \\
\end{array}$ & $\mathbf{N}$ & Mean & SD & $t$ Value & SIG \\
\hline \multirow{2}{*}{ Research Funding } & Associate Professor or Up & 48 & 2.8333 & .80776 & \multirow{2}{*}{-.950} & \multirow{2}{*}{.344} \\
\hline & Assistant Professor & 72 & 2.9722 & .76861 & & \\
\hline \multirow{2}{*}{ Organizational Climate } & Associate Professor or Up & 48 & 3.6250 & .66177 & \multirow{2}{*}{$3.114^{* *}$} & \multirow{2}{*}{.002} \\
\hline & Assistant Professor & 72 & 3.1389 & 1.04776 & & \\
\hline \multirow{2}{*}{ Hardware and Facilities } & Associate Professor or Up & 48 & 3.2917 & .84949 & \multirow{2}{*}{-.076} & \multirow{2}{*}{.939} \\
\hline & Assistant Professor & 72 & 3.3056 & 1.05669 & & \\
\hline \multirow{2}{*}{ Human Resources } & Associate Professor or Up & 48 & 3.1250 & .53096 & \multirow{2}{*}{-.117} & \multirow{2}{*}{.907} \\
\hline & Assistant Professor & 72 & 3.1389 & .76861 & & \\
\hline \multirow{2}{*}{$\begin{array}{l}\text { Library and Journal } \\
\text { Resources }\end{array}$} & Associate Professor or Up & 48 & 3.1250 & .77070 & \multirow{2}{*}{-.729} & \multirow{2}{*}{.467} \\
\hline & Assistant Professor & 72 & 3.2222 & .67599 & & \\
\hline
\end{tabular}

$* \mathrm{P}<.05 ; * * \mathrm{P}<.01$

Table 6 reports the $t$-test of the opinions of Taiwanese professors who worked in different types of universities. Professors who worked at universities awarded world class university funds tended to feel greater satisfaction with hardware and facilities and their library resources than other professors.

Table 6. Taiwanese Professors' Perceived Satisfaction with Influential Factors: Comparison of universities with world class university funds or not

\begin{tabular}{|c|c|c|c|c|c|c|}
\hline & $\begin{array}{l}\text { University Received World } \\
\text { Class University Funds? }\end{array}$ & $\mathbf{N}$ & Mean & SD & $t$ Value & SIG \\
\hline \multirow{2}{*}{ Research Funding } & Yes & 36 & 3.0000 & .99523 & \multirow{2}{*}{.655} & \multirow{2}{*}{.515} \\
\hline & No & 84 & 2.8810 & .67790 & & \\
\hline \multirow{2}{*}{ Organizational Climate } & Yes & 36 & 3.5000 & .99043 & \multirow{2}{*}{1.274} & \multirow{2}{*}{.205} \\
\hline & No & 84 & 3.2619 & .91554 & & \\
\hline \multirow{2}{*}{ Hardware and Facilities } & Yes & 36 & 3.8333 & .69693 & \multirow{2}{*}{$4.185^{* * *}$} & \multirow{2}{*}{.000} \\
\hline & No & 84 & 3.0714 & .99136 & & \\
\hline \multirow{2}{*}{ Human Resources } & Yes & 36 & 3.2778 & .76636 & \multirow{2}{*}{1.529} & \multirow{2}{*}{.129} \\
\hline & No & 84 & 3.0714 & .63598 & & \\
\hline \multirow{2}{*}{$\begin{array}{l}\text { Library and Journal } \\
\text { Resources }\end{array}$} & Yes & 36 & 3.4444 & .69465 & \multirow{2}{*}{$2.691^{* *}$} & \multirow{2}{*}{.008} \\
\hline & No & 84 & 3.0714 & .69627 & & \\
\hline
\end{tabular}


Table 7 reports the $t$-test of the opinions of Taiwanese professors who worked in different locations. Professors who worked at universities in other cities tended to feel more satisfied with their library resources than other professors.

Table 7. Taiwanese Professors' Perceived Satisfaction with Influential Factors: Comparison of university locations

\begin{tabular}{|c|c|c|c|c|c|c|}
\hline (a) & $\begin{array}{c}\text { University } \\
\text { Location }\end{array}$ & $\mathbf{N}$ & Mean & SD & $t$ Value & SIG \\
\hline \multirow{2}{*}{ Research Funding } & Six Urban Cities & 90 & 3.0000 & .70312 & \multirow{2}{*}{1.753} & \multirow{2}{*}{.087} \\
\hline & Other Cities & 30 & 2.6667 & .95893 & & \\
\hline \multirow{2}{*}{ Organizational Climate } & Six Urban Cities & 90 & 3.4000 & .86721 & \multirow{2}{*}{1.349} & \multirow{2}{*}{.180} \\
\hline & Other Cities & 30 & 3.1333 & 1.12648 & & \\
\hline \multirow{2}{*}{ Hardware and Facilities } & Six Urban Cities & 90 & 3.3333 & .88262 & \multirow{2}{*}{.647} & \multirow{2}{*}{.519} \\
\hline & Other Cities & 30 & 3.2000 & 1.22428 & & \\
\hline \multirow{2}{*}{ Human Resources } & Six Urban Cities & 90 & 3.2000 & .65686 & \multirow{2}{*}{1.877} & \multirow{2}{*}{.063} \\
\hline & Other Cities & 30 & 2.9333 & .72397 & & \\
\hline \multirow{2}{*}{$\begin{array}{l}\text { Library and Journal } \\
\text { Resources }\end{array}$} & Six Urban Cities & 90 & 3.1111 & .78054 & \multirow{2}{*}{$-2.639^{*}$} & \multirow{2}{*}{.010} \\
\hline & Other Cities & 30 & 3.4000 & .39538 & & \\
\hline
\end{tabular}

\section{CONCLUSION}

This research constructed the five dimensions of research influential factors: research funding, organizational climate, hardware and facilities, human resources, and library and journal resources. University professors in Taiwan generally considered governmental research funding to be the most important indicator, followed by students' academic ability and digital library resources. According to Taiwanese professors, paper resources are not important. Colleagues' collaboration and discussion spaces also received the lowest importance weights.

Although faculty perceived satisfaction with the influential factors at their universities, they perceived the lowest satisfaction with governmental research funding, institutional research funding, and students' academic ability. These three factors were the highest weighted indicators rated by Taiwanese professors. This preliminary research finding confirms the importance of fund resources and students' academic ability on factors of research production. However, future analysis should focus on the differences of weights professors gave to influential indicators on research production based on professors' backgrounds. For example, do junior faculty rate different weights than senior professors? Do different research fields become key characteristics for determining weight differences when professors consider influential indicators on research production?

This research also identified some significant differences among Taiwanese professors' opinions on influential factors used in universities and their satisfaction with these factors. For example, male professors felt significantly higher satisfaction with their research funding than female professors. Female professors were significantly more satisfied with their hardware and facilities than male professors. Furthermore, associate professors and professors felt significantly higher satisfaction with the organizational climate than assistant professors. Finally, professors who worked at universities award by the Ministry of Education in Taiwan's "building world class university program" tended to experience greater satisfaction with hardware and facilities and their library resources than other professors. These findings confirm certain structural inequalities within Taiwanese universities, such as issues of inequalities among gender, age (seniority issues), and world class university or not (an issue of the stratification of higher education).

\section{AUTHOR BIOGRAPHY}

Yang, Cheng-Cheng is an associate professor in the Graduate Institute of Educational Administration and Policy Development at National Chiayi University, Taiwan. His research interests include higher education administration and policy and international comparative education. His research articles cover topics ranging from higher education management to higher education policies in Taiwan and other Asian countries. In recent years, he has focused on finding influential factors of faculty members' research and teaching performance at universities in Taiwan. He also continued studying the impacts of higher education expansion in Taiwan. 


\section{REFERENCES}

Blackburn, R. T. \& Bentley, R. J. (1993). Faculty research productivity: Some moderators of associated stressors. Research in Higher Education, 34(6), 725-745.

Campbell, D. F. J. (2002). Conceptual framework for the evaluation of university research in Europe. Retrieved December 25 , 2012 from http://www.gwu.edu/ cistp/PAGES/campbell_2002.pdf

Chang, C. Y., \& Chiu, T. Y. (2008). A study on index weights for assessing university professors' research performance. Journal of National Taipei University of Technology, 41(1), 89-106.

Chen, D., \& Lo, W. (2013). Internationalization or commodification? A case study of internationalization practices in Taiwan's higher education. Asia Pacific Education Review, 14(1), 33-41.

Chen, Y., Gupta, A., \& Hoshower, L. (2006). Factors that motivate business faculty to conduct research: An expectancy theory analysis. Journal of Education for Business, 81(4), 179-189.

Creswell, J. W. (1985). Faculty research performance: Lessons from the sciences and the social sciences. ASHE-Eric Higher Education Report No.4.

Giroux, H. A. (2002). Neoliberalism, corporate culture, and the promise of higher education: The university as a democratic public sphere. Harvard Educational Review, 72(4), 425-464.

Ho, H. F. (2013). Ideal careers perceived by education major undergraduates in Taiwan. International Education Studies, 6(4), $39-46$.

Hou, A. Y. C. (2012). Impact of excellence programs on Taiwan higher education in terms of quality assurance and academic excellence, examining the conflicting role of Taiwan's Accrediting agencies. Asia Pacific Education Review, 13(1), $77-$ 88.

Kotrlik, J. W., Bartlett, J., Higgins, C., \& Williams, H. (2001). Factors associated with research productivity of agricultural education faculty. Proceedings of the $28^{\text {th }}$ Annual National Agricultural Education Research Conference (pp. 195-206), XXVIII.

Kyvik, S. \& Smeby, J. C. (1994). Teaching and research: The relationship between the supervision of graduate students and faculty research performance. Higher Education, 28(2), 227-239.

Lin, Y. F. \& Chan, S. J. (2004). On the differentiation framework of the post-compulsory education in Taiwan: A perspective based on the reflection on the two-educational highway policy. Educational Research \& Information, 12(6), 59-84.

Lo, W. (2009). Reflections on internationalization of higher education in Taiwan: Perspectives and prospects. Higher Education, $58,733-745$.

Ministry of Education in Taiwan. (2017). Statistics of the number of higher education institutions in Taiwan. Retrieved from http://stats.moe.gov.tw/files/important/OVERVIEW_U03.pdf

Moran, E. T., \& Volkwein, J. F. (1988). Examining organizational climate in institutions of higher education. Research in Higher Education, 28(4), 367-383.

Olssen, M. \& Peters, M. A. (2005). Neoliberalism, higher education and the knowledge economy: From the free market to knowledge capitalism. Journal of Education Policy, 20(3), 313-345.

Saaty, T. L. (1990). Decision making for leaders: The analytic hierarchy process for decisions in a complex world. Pittsburgh, PA: RWS Publications.

Zhang, Y. B., Lin, M. C., Nonaka, A., \& Beom, K. (2005). Harmony, hierarchy and conservatism: A crosscultural comparison of Confucian values in China, Korea, Japan, and Taiwan. Communication Research Report, 22, 107-115. 